Revue d'histoire de l'Amérique française

REYUE D.HISTOIRE DE L'AMÉRIQUE FRANÇAISE

\title{
Oblats de Colombie
}

LAMIRANDE, Émilien, o.m.i., Projet de fondation oblate en

Californie (1849-1853). Un chapitre des relations entre Jésuites

et Oblats en Orégon. Tiré à part de Études oblates, revue

trimestrielle publiée par les Oblats de Marie-Immaculée de la province Saint-Joseph (Canada), tome XXII (1963), bro., 38 p.

\section{Lionel Groulx}

Volume 17, numéro 3, décembre 1963

URI : https://id.erudit.org/iderudit/302301ar

DOI : https://doi.org/10.7202/302301ar

Aller au sommaire du numéro

Éditeur(s)

Institut d'histoire de l'Amérique française

ISSN

0035-2357 (imprimé)

1492-1383 (numérique)

Découvrir la revue

Citer ce compte rendu

Groulx, L. (1963). Compte rendu de [Oblats de Colombie / LAMIRANDE, Émilien, o.m.i., Projet de fondation oblate en Californie (1849-1853). Un chapitre des

relations entre Jésuites et Oblats en Orégon. Tiré à part de Études oblates, revue trimestrielle publiée par les Oblats de Marie-Immaculée de la province

Saint-Joseph (Canada), tome XXII (1963), bro., 38 p.] Revue d'histoire de

l'Amérique française, 17(3), 449-449. https://doi.org/10.7202/302301ar d'utilisation que vous pouvez consulter en ligne. 
Oblats DE Colombie. - Emilien Lamirande, o.m.i., Projet de fondation oblate en Californie (1849-1853). - Un chapitre des relations entre Jésuites et Oblats en Orégon. Tiré à part de Etudes oblates, revue trimestrielle publiée par les Oblats de Marie-Immaculée de la province Saint-Joseph (Canada), tome XXII (1963), bro., 38 pages.

Cette étude d'un spécialiste de l'histoire des Oblats évoque le fervent enthousiasme de la jeune communauté prête à conquérir le monde. Cette page de l'histoire oblate appartient aussi, au moins par un lien, à l'histoire du Canada français missionnaire. C'est de Mgr F.-N. Blanchet, premier archevêque d'Oregon City, que les Oblats reçoivent, en 1946, leur premier appel vers cette région. C'est à la requête de Mgr A.-M.-A. Blanchet, évêque de Walla-Walla, que cinq Oblats partent pour l'Orégon en 1947. Pendant une trentaine d'années, ils y exerceront un ministère "plutôt ingrat", mais ce sera pour eux le tremplin d'où ils s'élanceront vers la Colombie britannique où ils vont accomplir "une œuvre de premier plan". Il y a donc là une page que les historiens de l'Eglise canadienne ne sauraient négliger. L.G. 